ISSN 1112-9867

Available online at $\quad$ http://www.jfas.info

\title{
FEATURES OF HUMAN CAPITAL IN URBAN TERRITORIES
}

\author{
Z. Mingaleva ${ }^{1, *}$, Y. Karpovich ${ }^{1}$, O. Kozlova ${ }^{2}$ \\ ${ }^{1}$ Perm National Research Polytechnic University, 29, Komsomolsky Av., Perm, 614000, \\ Russia \\ ${ }^{2}$ Institute of Economics, Ural Branch of the Russian Academy of Sciences, 29, Moskovskaya \\ st., Yekaterinburg, 620014, Russia \\ Published online: 08 August 2017
}

\begin{abstract}
The article is devoted to the peculiarities of the agglomeration processes in Russia that are associated with the transition from the industrial phase to the post-industrial phase of the urbanization. Comparative analysis of results of transition processes in Perm and Yekaterinburg areas is given. Special attention is paid to human capital agglomeration, which is regarded as a component of territorial capital. The calculations of human capital of agglomerated areas in general and of centers of agglomerated areas are carried out. The article contains conclusions on the relationship of human capital as a tangible asset of a big city with the development of specific social capital of the city, aimed at active policy of urbanization. As a theoretical framework it is proposed to use the territorial capital theory.
\end{abstract}

Keywords: urbanization; agglomeration; human capital; territorial capital.

\section{INTRODUCTION}

To provide high rates of sustainable economic growth Russia should proceed to the development on the basis of the so-called new "portfolio of resources" (human capital, capacious and dynamic markets, innovations, high-tech fixed assets and post-industrial type of production). Urban areas are the loci of post-industrial development processes and in this regard they are the sources of future competitiveness of Russia in the global economy.

Author Correspondence, e-mail: mingal1@psu.ru

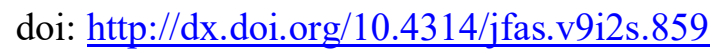


Therefore, intensive development of large urban agglomerations is an important objective in the development strategy of the Russian Federation in the long term.

The concepts of urbanization and urban agglomeration can be interpreted in a more narrow sense as the growth of cities and increasing the number and share of urban population, and from a broader perspective as considering the increasing role of cities and the urban lifestyle in the development of society. Urban agglomeration is a phenomenon that is inextricably linked with the process of urbanization. This is the process of combining neighboring urban settlements in a single complex and integrated system. Sustainable and intensive communications are formed within this system: production, transport, scientific and cultural ones. Urban agglomeration is one of the logical stages of urbanization processes.

Agglomerationsare especially in demand in Russia with its vast spaces and distances. Effective economic contraction of the territory takes placedue to them. The most important objects of industry, science, education, culture and recreation are concentrated in agglomerations. The proportion of near relations geographically isolated in small agglomeration areas increases thanks to the contiguity of these interacting objects within the agglomerations. It gives significant social and economic effect.

\section{Theory}

Industrial agglomerations were created in Russia by administrative way; economic ties between enterprises and organizations were formed prescriptively. Large-scale socioeconomic changes in the country led to the abandonment of planning in various fields, including urban and regional planning. According to the approach proposed by Edward Bose, the process of transition from industrial to post-industrial agglomeration which takes place nowadays in Russia has three main phases: transformation, dynamic agglomeration and a developed post-industrial agglomeration (Bose, 2007). These phases combine the complex of real socio-economic processes changing functional and spatial structure of the economy of the territory and which are the basis for making major investment and innovation decisions by the Federal and regional authorities (Mingaleva, and Mingaleva, 2013). Key features of the different phases of agglomeration development are presented in table 1. 
Table 1. The main stages of the development of modern urban agglomeration

\begin{tabular}{|c|c|c|c|}
\hline $\begin{array}{c}\text { Industria } \\
\quad 1 \\
\text { agglomer } \\
\text { ation }\end{array}$ & $\begin{array}{l}\text { Transfor } \\
\text { mation }\end{array}$ & $\begin{array}{l}\text { Dynamic } \\
\text { agglomer } \\
\text { ation }\end{array}$ & Developed post- industrial agglomeration \\
\hline $\begin{array}{l}\text { Industrial } \\
\text { productio } \\
\mathrm{n} \text { is the } \\
\text { basic } \\
\text { function }\end{array}$ & $\begin{array}{l}\text { Growth of } \\
\text { the service } \\
\text { sector and } \\
\text { the labor } \\
\text { market in } \\
\text { the core of } \\
\text { agglomerat } \\
\text { ion }\end{array}$ & $\begin{array}{c}\text { Relocatio } \\
\mathrm{n} \text { of } \\
\text { productio } \\
\mathrm{n} \text { and } \\
\text { centers of } \\
\text { consumpti } \\
\text { on and } \\
\text { entertain } \\
\text { ment to } \\
\text { the } \\
\text { periphery }\end{array}$ & $\begin{array}{l}\text { Developing chordate relationships between the sub- } \\
\qquad \text { centers }\end{array}$ \\
\hline $\begin{array}{c}\text { There is } \\
\text { no single } \\
\text { labor } \\
\text { market, } \\
\text { real estate } \\
\text { market }\end{array}$ & $\begin{array}{l}\text { Emergence } \\
\text { of } \\
\text { centripetal } \\
\text { pendulum } \\
\text { labour } \\
\text { migration }\end{array}$ & $\begin{array}{c}\text { Single } \\
\text { market of } \\
\text { commerci } \\
\text { al, } \\
\text { residential } \\
\text { and } \\
\text { industrial } \\
\text { real estate }\end{array}$ & $\begin{array}{c}\text { New capacity of the common market and the } \\
\text { mobilization of diverse resources }\end{array}$ \\
\hline $\begin{array}{c}\text { A } \\
\text { significan } \\
\mathrm{t} \\
\text { difference } \\
\text { in social } \\
\text { policy, } \\
\text { the level }\end{array}$ & $\begin{array}{l}\text { Significant } \\
\text { difference } \\
\text { in social } \\
\text { policy, the } \\
\text { level and } \\
\text { quality of } \\
\text { life in the }\end{array}$ & $\begin{array}{l}\text { Growth of } \\
\text { the } \\
\text { welfare of } \\
\text { the } \\
\text { inhabitant } \\
\text { s of the } \\
\text { periphery, }\end{array}$ & $\begin{array}{c}\text { Creation of new working places, including places in } \\
\text { the innovation sector, on the periphery of the } \\
\text { agglomeration }\end{array}$ \\
\hline
\end{tabular}




\begin{tabular}{|c|c|c|c|}
\hline $\begin{array}{c}\text { and } \\
\text { quality of } \\
\text { life in the } \\
\text { centre } \\
\text { and the } \\
\text { periphery }\end{array}$ & $\begin{array}{l}\text { centre and } \\
\text { on the } \\
\text { periphery }\end{array}$ & $\begin{array}{l}\text { suburbani } \\
\text { zation } \\
\text { processes }\end{array}$ & \\
\hline $\begin{array}{c}\text { A } \\
\text { significan } \\
\mathrm{t} \\
\text { difference } \\
\text { between } \\
\text { the } \\
\text { economic } \\
\text { capacity } \\
\text { of the } \\
\text { centre } \\
\text { and the } \\
\text { periphery }\end{array}$ & $\begin{array}{l}\text { Significant } \\
\text { difference } \\
\text { between } \\
\text { the } \\
\text { economic } \\
\text { capacity of } \\
\text { the centre } \\
\text { and the } \\
\text { periphery }\end{array}$ & $\begin{array}{l}\text { Reorganiz } \\
\text { ation and } \\
\text { moderniza } \\
\text { tion of the } \\
\text { productio } \\
n \\
\text { complex, } \\
\text { the } \\
\text { formation } \\
\text { of the } \\
\text { processin } \\
\text { g centers } \\
\text { on the } \\
\text { periphery }\end{array}$ & $\begin{array}{l}\text { High level of functional connectivity between all } \\
\text { elements of the agglomeration }\end{array}$ \\
\hline $\begin{array}{l}\text { The basis } \\
\text { of the } \\
\text { relationsh } \\
\text { ip: } \\
\text { productio } \\
\text { n } \\
\text { cooperati } \\
\text { on and } \\
\text { familyties }\end{array}$ & $\begin{array}{c}\text { Emergence } \\
\text { of a } \\
\text { unified } \\
\text { large and } \\
\text { diverse } \\
\text { labour } \\
\text { market } \\
\text { with } \\
\text { concentrati } \\
\text { on in the } \\
\text { core of the } \\
\text { agglomerat }\end{array}$ & $\begin{array}{c}\text { A single, } \\
\text { functional } \\
\text { ly } \\
\text { coherent } \\
\text { urban } \\
\text { agglomera } \\
\text { tion, } \\
\text { developed } \\
\text { transport } \\
\text { and } \\
\text { logistics } \\
\text { complex }\end{array}$ & $\begin{array}{c}\text { Activeintegrationintotheglobalhierarchyofurbancenters } \\
\text { andworktoimprovethestatus }\end{array}$ \\
\hline
\end{tabular}




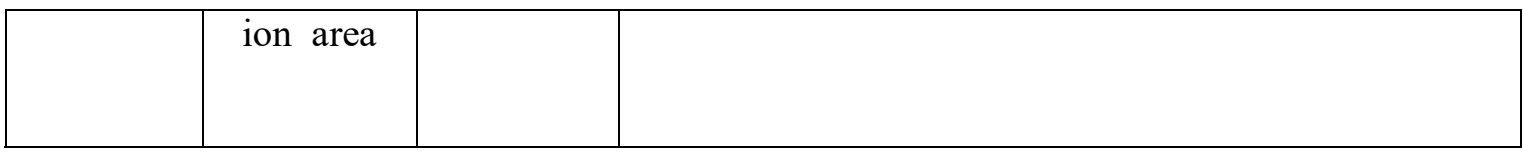

Moscow and St. Petersburg agglomerations are the closest to the post-industrial stage of development according to expert estimates, however, they do not correspond to the characteristics of the post-industrial stage for a number of the above signs of agglomeration.

Therefore, agglomeration is characterized today not only with the integrity of the production and settlement systems but also with the integrity of the markets: labour,real estate, land, as well as the level of functional connectedness of its separate elements. In this regard, issues associated with the dynamics of human capital in territorial aspect are of particular interest. Agglomeration is an effective form of concentration of human capital, intellectual opportunities and prerequisites for innovative development. Its main advantage is the socalled synergistic effect. It draws investment and brings benefits from the use of labor and other resources which are powerful factors of increasing the competitiveness and attractiveness of territorial systems.

Certain market and non-market forces influencing the processes of human capital accumulation in agglomerations due to its inflow from the region, include the division of labour, lower costs of search of place of work and the right employee, the size of the market. The urban market which is large in size and much denser provides greater diversity of products, offering a higher level of consumption to the diversified economy. Increase of the optimal size of cities due to agglomeration also occurs as a result of exogenous technological changes that reduce the transportation costs of workers in an urban setting.

It is known that the demand for food produced in rural areas becomes inelastic to the income growth(Millward, 2006). This means that the growth of real income of the population begins to reduce accordingly the demand for food in rural areas. Labour force is induced to move from the countryside to the city, it leads to the increase of demand for the goods produced in it. Rural residents move to the urban sector as a result of agglomeration (Karlsson et al., 2009).

\section{METHODOLOGY}

The study is based on scientific methodology that involves an integrated, systematic approach to solving problems of human capital, as well as providing unity historical and logical, qualitative and quantitative analysis to ensure the validity of the results of the study and makes it possible to consider human capital as a complex, multifaceted phenomenon, the 
study of which requires the use of theoretical and empirical methods of cognition. The authors of the study relied on the position of the leading Russian and foreign scientists in the field of economic theory and labor market, social and labor relations, demography, regional economy development of human capital.

Spatial development by promoting integrative processes (Bochco, 2010), as world practice shows, is a powerful tool for building and implementing human capital, which, ultimately, contributes to the development of social infrastructure, improvement of the quality of employment, increase of wages of deductions to the budgets of different levels, enhancing the sustainability and competitiveness of the regional economy.

The most essential influence on the human capital is rendered by external socio-economic ones, such as general dynamics of microeconomic indicators, structural changes, the situation in financial and investment spheres, level of income, as well as development level of territorial economy's infrastructure. The economic aspect of human capital management assumes achievement of compliance of production and resource security of territories, including the consideration of migratory process nature (Franco, 2008).

\section{DISCUSSION}

Currently there are several approaches to the analysis of territorial capital of agglomerations. One of the approaches, proposed by R. Giffinger and M. Stalbaum, refers to functional theories (Giffinger, 2009). In accordance with this approach the main contribution of territorial capital to the development of the agglomeration area lies in the special relationship of all its components which include natural characteristics, tangible and intangible cultural, technological and social heritage. A common characteristics of territorial capital, uniting all its elements, are such interdependences as customs, informal rules, understanding and specific practices (institutions, policies, joint strategies and policies)(Graham, 2008).

On this basis, we can determine two parameters that measure potential sources of territorial capital; they are its materiality and the competition with other agglomerations. The first parameter enables the production of material goods, and competition provides society with intangible benefits that can be identified as intangible assets based on social, cultural and institutional capital. Thus, the territorial capital is dependent on the qualitative characteristics of the area, defined by its tangible and intangible assets and provided by the functional elements and joint initiatives. As it was pointed out by Camagni R. (2009) these assets provide the absolute and relative comparative advantages of the territory (Camagni, 2009). It means that the territorial capital strengthens the relationship of cities or separate groups of 
participants of social relations (public, entrepreneurs) or the formation of clusters, emerging where people can buy and share with each other the necessary knowledge.

Over 30 agglomerations are distinguished in Russia, most of them are now at the transformation stage. For further studies wechose two agglomerations - Perm agglomeration and Yekaterinburg one. The choice was made because key quantitative indicators of these agglomerations are comparable, Yekaterinburg is on the fifth place in the ranking of agglomerations, and the Perm rating is 9 of 36 Russian agglomerations (Percik, 2009). Moreover, these agglomerations are located in the Urals and are neighbors (by Russian standards), have similar natural and climatic conditions, the formation and development of the two cities under consideration have identical trajectories.

Perm agglomeration includes Perm, Krasnokamsk, Nytva, Dobriansky areas. The economy and population are increasingly concentrated around the core of the agglomeration, i.e. in Perm and Krasnokamsk, while in urban areas which are the satellites of the agglomeration from Vereshchagino to Kungur, and from the South-Kamsky area to Dobryanka lives just over $15 \%$ of the population of the agglomeration.

Conventionally, the composition of the Yekaterinburg agglomeration consists of 5 municipalities: city district Aramil, Berezovsky urban district, urban district of Rezh, Sysert urban district, municipal formation "City of Ekaterinburg".

The industry in Ekaterinburg agglomeration is connected with heavy engineering, in Perm with electric power, oil and gas refining, machine building, chemistry and petrochemistry. On the volume of industrial production Perm currently ranks first in the Urals, ahead of Yekaterinburg. The structure of industry in Perm agglomeration is more diverse than in Yekaterinburg, and a number of industrial sectors have high export potential and developsuccessfully in a market environment (Mingaleva,Bykova, \& Lobova, 2013). As a result Perm agglomeration has a fairly good situation with the occupancy of the city budget (Korchagin, 2011). In the ranking of fiscal capacity and spending per capita among 15 largest cities of Russia (exluding Moscow and St. Petersburg) Krasnoyarskis on the first place with the spending equal to 23,2 thousand rbl. per capita. Perm occupies the second place $(20,3$ thousand rubles per capita), Yekaterinburg ranked the 6th with 18.7 thousand rubles per capita.

In this way, the cities have a comparable population, climatic conditions, and on a number of tangible assets, the Perm has advantages compared to Ekaterinburg (natural resources, economic structure, financial results of enterprises). 
However, a higher place of Ekaterinburg in regional and urban hierarchy is illustrated by the following facts. Yekaterinburg is linked to 28 foreign and 24Russian cities with scheduled flights, while the Perm has air links only with 8 foreign cities and 7 Russian ones.

A large number of offices of political organizations of the Ural Federal district and VolgaUral military district, representative offices of a number of subjects of the Russian Federation, consulates of 14 countries (including the UK, China, USA, Germany, France), as well as the offices of the Trade Council of Denmark and the support center of Dutch business are concentrated in Ekaterinburg.

A branch of higher education in Ekaterinburg is presented with 17 separate educational institutions (excluding branches), while in Perm there are only 6 educational institutions. In Ekaterinburg there is also the Ural branch of the Russian Academy of Sciences (the structure of which includes scientific councils, editorial boards of scientific journals, research institutions).

In general, Yekaterinburg in comparison with Perm has the most inherent traits that characterize the city's ability to pursue a metropolization policy described by R. M. Giffinger and Stallbohm (Giffinger et al., 2009) . The main features of the metropolization policy are:

- spatial expansion of the city, involving the creation of socio-economic sub-centers, the intensive creation of new working places on the basis of a polycentric model;

- intensive development of the economy based on knowledge, as in the manufacturing sector and the service sector, both in the centre and on the periphery of the agglomeration;

- concentration of decision making centers in city such as international and inter-regional manufacturing and service businesses, political, public and cultural organizations.

The combination of these characteristics leads to the fact that the Perm loses its competitiveness compared to other major cities. Objectively, it is manifested in the following negative tendencies of development of the Perm: a model of monocentric economic structure, the decline of the population, negative migration of the most mobile categories of the population, the stagnation in the labour market.

Meanwhile, the absence of themetropolisation policy not only reduces the competitiveness of major cities, but also creates preconditions of decline in the region as a whole. The objective processes of population concentration in agglomerations will find alternative areas in neighbouring regions, and less adaptive populations that are not inclined to relocate, in the low-skill jobs will play backward model of regional and urban development.

At the same time, agglomeration development is impossible without development of human capital. Research conducted by Rosenthal and Strange (2004) showed that the process of 
agglomeration leads to productivity increase from 3 to 8 percent (Rosenthal, 2004). The growing demand for educated and skilled labour force within the agglomeration area leads to higher wage level for these categories of workers, attracting an even greater number of people to the agglomeration. Large agglomerated areas offer more "liquid" jobs for people with narrow specialization.

Despite the considerable difference in wage levels between countries and within countries, comparative analysis of wages, correlated with levels of human capital within an agglomeration, so far received insufficient attention (Burchfield, 2006). For the first time the relationship between the agglomeration of human capital and prosperity of the region was defined by Myrdal (1954), Kuznets (1962), Hirschmann (1958) and was particularly emphasized by Kaldor (1970), who established that the territorial agglomeration of human capital gives a better return compared to the return on investment in human capital at the level of the individual.

As tools for territorial division of human capital Heuermann D. proposes to use the number of students attending educational institutions within the agglomeration area, as far as students from areas outside it are studying in educational institutions located throughout the agglomeration area along with its inhabitants, entering upon graduation to the labour market of the same agglomerations (Heuermann, 2003). This approach to the analysis of human capital agglomeration is based on the following assumptions:

- $\quad$ territorial density of human capital affects the wages of skilled and unskilled workers, - $\quad$ improvement of professional skill of workers affects negatively the wages of high skilledworkers and positively the wages of low skilled workers.

For the comparative analysis of human capital in territorial aspect, we used a method proposed by Kornejchuk V., allowing a comprehensive quantification of human capital according to the following criteria (Korneychuk, 2004):

1. The educationallevel of residents of the region. This figure is equal to the proportion of the most educated workers in total employment in the economy of the territory. It is generally considered that the category of the most educated employees includes employees with higher professional education (finished or unfinished) and secondary vocational education.

2. The "width" of human capital is calculated by multiplication of the region's population by the level of education.

3. The "length" of human capital (health level) equals to life expectancy at birth. The value of human capital of the population of the region is the result of multiplication of the "width" by the "length"of human capital of the agglomeration. 
These indicators can be supplemented with such parameters as population density and percentage of urban population of agglomerations in order to conduct a comparative analysis of human capital between the agglomerations. The results of calculation which are presented in table 2 were calculated on data collected by Rosstat from the municipal statistics.

Table 2. Indicators of human capital in Perm and Perm agglomeration

\begin{tabular}{|l|l|l|c|}
\hline Indicator & Perm city & $\begin{array}{l}\text { Perm } \\
\text { agglomeration }\end{array}$ & $\begin{array}{l}\text { Perm city in } \\
\text { comparison with the } \\
\text { agglomeration }\end{array}$ \\
\hline Educational level, \% & $87 \%$ & $48 \%$ & +39 \\
\hline $\begin{array}{l}\text { Width of human capital, thous. } \\
\text { people }\end{array}$ & 858,3 & 720 & $+138,3$ \\
\hline $\begin{array}{l}\text { Lengthofhumancapital, years } \\
\text { Human capital, thous. man-years }\end{array}$ & 66,25 & 66 & $+0,25$ \\
\hline $\begin{array}{l}\text { Population density, thousand } \\
\text { people/sq. km. }\end{array}$ & 1,23 & 0,13 & +9340 \\
\hline
\end{tabular}

These figures indicate that although the population of Perm agglomeration 1,22 times higher than the population of Perm city, the values of all indicators of human capital in the city exceed the values of Perm agglomeration.

A comparative study of Perm and Yekaterinburg agglomerations was carried out in a similar way using additional indicators (see tab.3). 
Table 3. Comparison of Perm and Yekaterinburg agglomerations

\begin{tabular}{|c|c|c|c|}
\hline Indicator & $\begin{array}{l}\text { Perm } \\
\text { agglomeration }\end{array}$ & $\begin{array}{l}\text { Yekaterinburg } \\
\text { agglomeration }\end{array}$ & $\begin{array}{l}\text { Yekaterinburg } \\
\text { agglomeration in } \\
\text { comparison with the } \\
\text { Perm agglomeration }\end{array}$ \\
\hline Educational level, \% & $48 \%$ & $52 \%$ & +4 \\
\hline $\begin{array}{l}\text { Width of human capital, thous. } \\
\text { people }\end{array}$ & 720 & 842 & +122 \\
\hline Lengthofhumancapital, years & 66 & 67,7 & $+1,7$ \\
\hline Human capital, thous. man-years & 47520 & 57003,4 & $+9483,4$ \\
\hline $\begin{array}{l}\text { Population density, thousand } \\
\text { people/sq. km. }\end{array}$ & 0,13 & 0,33 & $+0,2$ \\
\hline $\begin{array}{l}\text { The share of urban population in } \\
\text { the population of } \\
\text { agglomeration, } \%\end{array}$ & 66 & 94,4 & $+28,4$ \\
\hline $\begin{array}{l}\text { Natural increase of population, } \\
\text { persons per } 1,000 \text { population }\end{array}$ & $-1,8$ & $+0,5$ & $+2,3$ \\
\hline Average wage, rubles (2015) & 22097 & 26762 & +4665 \\
\hline $\begin{array}{l}\text { The number of employed } \\
\text { persons (2015) according to } \\
\text { Rosstat }\end{array}$ & 829343 & 1060310 & +230967 \\
\hline $\begin{array}{l}\text { The number of inhabitants of the } \\
\text { city (center of agglomeration), } \\
\text { thousand people (on January 1, } \\
2015 \text { ) }\end{array}$ & 1036469 & 1428042 & +391573 \\
\hline
\end{tabular}

The population in Yekaterinburg agglomeration exceeds the population of Yekaterinburg 1.5 times, the corresponding figure for the Perm agglomeration is 1,22 . The number of inhabitants in Yekaterinburg for the last 8 years has grown by $4 \%$ and in Perm this indicator decreased by $2 \%$.

Thus, both Yekaterinburg and Perm agglomerations are at the stage of transformation from the industrial phase of development to a dynamic one. However, Yekaterinburg has always been a way to move more successfully by regulating the agglomeration process, due to the 
policies of metropolisation, through the creation of a specific social capital of the city. In Perm, on the contrary, sintering processes proceed spontaneously, there is no governing policy in this area.

\section{SUMMARY}

Therefore, the formation of a specific human capital in the city (core of agglomeration) determines the direction and success of the transformation of the agglomeration in a dynamic phase. At the same time, in the absence of a deliberate policy of metropolisation, special case of transformation is possible, when the agglomeration is losing some of the characteristics of the industrial phase, for example, cooperative communication of manufacturing enterprises, but there is no evolutionary development in the direction of the dynamic and post-industrial phases. Such unregulated transformation can "preserve itself" and lead to negative externalities.

We can also assume that in Yekaterinburg the administration was forced to pay special attention to the regulation and search for new opportunities of development of the urban economy, as in the beginning of the transformation of the city industry (heavy machinery) had a lower economic conditions than more diversified and open export industry in Perm.

Appropriate expansion of potentially suitable areas for external and internal investments, the strengthening of non-capital cities, increasing their independence and responsibility for strategy development are reasonable under conditions of depopulation. Polycentric development of the country and each city as the center of agglomeration will create conditions for improving territorial balance, improve conditions for economic development of Russian regions.

Dynamics and success of the agglomeration transformation influenced byhuman capital of the city (core of agglomeration) may provide greater value than the original material assets of the city (natural resources, climatic conditions, economic structure, etc.). At the same time, spatial agglomeration of human capital can provide an increasing return on investment only if the development strategy of the agglomeration as a whole and its core corresponds to the real state of the territorial capital tangible assets, as well as to the phase transformation of agglomeration.

\section{ACKNOWLEDGEMENT}

The work is carried out based on the task \#2014/152 on fulfillment of government contractual work in the field of scientific activities as a part of base portion of the state task of the 
Ministry of Education and Science of the Russian Federation to Perm National Research Polytechnic University (topic \#1487“'Innovative territorial development and the solution of urban problems").

Methodology of the research was worked out within the frames of grant RFFR 15-06-09169 «Development of methodological tools for measuring and assessing the impact of socioeconomic and medico-demographic factors on the mortality of the working age population».

\section{REFERENCES}

1. Bose E. (2007). Urban agglomeration: the old name of the new content. Russian expert review "Comfortable space of the city". № 4-5 (22).

2. Mingaleva Zh., \& Mingaleva A. (2013). Assessing Innovation Susceptibility of Regions and Municipal Districts. Procedia Social and Behavioral Sciences, 81, 595-599. DOI: $10.1016 /$ j.sbspro.2013.06.

3. Millward, H. (2006), "Urban Containment Strategies: A Case-Study Appraisal of Plans and Policies in Japanese, British and Canadian Cities", Land Use Policy, 23, pp.473485.

4. Karlsson, C.,Johansson,B.,\&Roger R. (2009). Stough Human Capital, Talent and Regional Growth/ CESIS Electronic Working Paper Series. Paper No. 191.

5. Giffinger R, Stallbohm M. (2009). Changes of metropolitan development: strategic efforts in comparison of Barcelona and Vienna. Paper presented at EUR \& UAA City Futures Conferences, Madrid.

6. Graham, D.J. \& Kim H.Y. (2008). An Empirical Analytical Framework for Agglomeration Economies, Annals of Regional Science, 42, 267-89.

7. Camagni R. (2009). Territorial capital and regional development. In R. Capello and P. Nijkamp (eds.) Handbook of Regional Growth and Development Theories. P. 118-132, Northampton, Mass.: Edward Elgar Publ.

8. Percik E.N. (2009). Large urban agglomerations: the development of design issues. Problems of development of agglomerations in Russia. M.: KRASANG, pp. 34-47.

9. Mingaleva, Zh., Bykova, E., \& Lobova, G. (2013). Motivation Processes of Educational Activities in Russia. Procedia Social and Behavioral Sciences, 83, 985-989. DOI: $10.1016 /$ j.sbspro.2013.06.183

10. Korchagin Y. Rated budget supply of the largest cities of Russia. Electronic resource: http://www.lerc.ru/?part=articles\&art=1\&page=77 (accessed at: 04.02.2011); 
11. Giffinger R, Stallbohm M. (2009). Changes of metropolitan development: strategic efforts in comparison of Barcelona and Vienna. Paper presented at EUR \& UAA City Futures Conferences, Madrid.

12. The most compelling city in Russia. Electronic resource: http://rating.rbc.ru/ articles/2010/11/16/33048061_tbl.shtml?2010/11/16/33048020 (accessed at 10.02.2011).

13. Rosenthal, S.S. \& W.C. Strange (2004). Evidence on the Nature and Sources of Agglomeration Economies, in Henderson, J.V. \& J.F. Thisse (2004) (Eds.), Handbook of Regional and Urban Economics, Vol. 4, Elsevier, Amsterdam, 2119-2171.

14. Heuermann,Daniel F. (208). Human Capital Externalities in Western Germany. Institute for Labour Law and Industrial Relations in the European Community. March 26, 2008.

15. Korneychuk, B.V. (2003). Human capital in the time dimension. / B.V. Korneychuk. $\mathrm{SPb} .:$ Publishing house of SPbSPU, $92 \mathrm{p}$.

16. Burchfield, M., H.G. Overman, D. Puga and M.Turner (2006). The Determinants of Urban Sprawl: A Portrait from Space, Quarterly Journal of Economics, 121(2), 587-633

17. Bochko, V.S. (2010).Integrative strategic development of areas (theory and methodology). Yekaterinburg: IE Uro ran.

18. Franco, S.(2008). Education, Health and Social Capital: A Cross-Country Analysis. Workshop on Social capital and Health. Paris - 10-11 October 2008.

\section{How to cite this article:}

Mingaleva Z, Karpovich Y, Kozlova O. Features of human capital in urban territories. J. Fundam. Appl. Sci., 2017, 9(2S), 1518-1531. 